\title{
Kajian Hidrostratigrafi Bentanglahan Kepesisiran Tipologi Marine Deposition Coast Kecamatan Ngambur Provinsi Lampung
}

\author{
Evi Mivtahul Khoirullah ${ }^{1}$, I.g.L.Setyawan Purnama², Margaretha Widyastuti ${ }^{2}$ \\ ${ }^{1}$ Mahasiswa Magister Fakultas Geografi UGM \\ ${ }^{2}$ Dosen Fakultas Geografi UGM
}

Korespondensi: evi.mivtahulk@mail.ugm.ac.id

\begin{abstract}
Abstrak
Penelitian ini dilakukan di wilayah kepesisiran yang berlokasi di Kecamatan Ngambur, Kabupaten Pesisir Barat, Provinsi Lampung. Secara geomorfologis tipologi wilayah kepesisiran ini berupa marine deposition coast yang terdiri dari bentuklahan gisik (M1), beting gisik (m2), dan dataran fluviomarin (Fm). Tujuan dari penelitian ini adalah merekonstruksi dan menganalisa karakteristik hidrostratigrafi yang meliputi sistem perlapisan batuan, sifat perlapisan batuan dan sifat air tanah yang ada pada daerah penelitian. Distribusi vertikal nilai tahanan jenis batuan diperoleh dengan melakukan pengukuran pada 24 titik pengukuran dengan kedalaman penetrasi hingga 150 meter. Pengukuran dilakukan dengan menggunakan metode purposive sampling. Selanjutnya nilai tahanan jenis hasil pengukuran diolah dengan menggunakan software IP2Win. Hasil pengolahan data dengan IP2Win dicocokkan dengan tabel resistivitas material. Hasil penelitian menunjukkan bahwa secara vertikal sistem perlapisan batuan yang teridentifikasi berupa akuifer, akuitard, dan akuifug. Material penyusun secara umum didominasi oleh material aluvium mengandung air tanah tawar yang berperan sebagai akuifer dan material batupasir yang berperan sebagai akuitard. Nilai daya hantar listrik (DHL) yang terukur $<1.200 \mathrm{mmhos} / \mathrm{cm}$ yang menunjukkan bahwa air tanah pada wilayah tersebut tergolong kedalam air tanah tawar.
\end{abstract}

Kata Kunci : Wilayah Kepesisiran, Akuifer, Hidrostratigrafi, Geolistrik.

\section{Abstract}

This research was conducted on coastal area located in Ngambur Subdistrict, Pesisir Barat Regency, Lampung Province. Geomorphologically, typology of this coastal area formed of marine deposition coast. Which is consist of sandy beach (M1), beach ridge (M2), and fluviomarine (Fm). The purpose of this reasearch is to reconstruct and analyze charactreistic of hydrostratigraphy which is includes of soil stratigraphy system and properties, and physical properties of groundwater in the research area. Vertical distribution of soil resistivity obtained by measuring 24 of measuring points with depth of penetration's up to 150 meters. Determination of measurement points are selected using purposive sampling method. Furthermore, the resistivity value of the measurement results is calculated using IP2Win software. Results of the calculation matched with soil resistivity tables. Results of the research show that vertically the type of aquifers identified are aquifer, aquitard, and aquifug. The constituent material is dominated by alluvium containing fresh groundwater which acts as an aquifer and sandstone materials which acts as aquitard. The electrical conductivity value (DHL) measured $<1,200 \mathrm{mmhos} / \mathrm{cm}$ which indicates that the groundwater in ths area is classified as fresh groundwater.

Key Words : Coastal Area, Aquifer, Hydrostratigraphy, Geoelectricity.

Kajian Hidrostratigrafi Bentanglahan Kepesisiran ...

Evi Mivtahul Khoirullah, I.g.L.Setyawan Purnama, Margaretha Widyastuti 


\section{Pendahuluan}

Wilayah kepesisiran ngambur merupakan bentanglahan kepesisiran kesatuan sistem marine deposition coast yang terbentuk akibat pengendapan material dari lautan. Bentanglahan kepesisiran yang terletak di pulau Sumatera ini secara umum terbentuk pada masa miosen akhir akibat penunjaman lempeng India-Australia yang menyebabkan bagian barat Pulau Sumatra terangkat dan bagian timur relatif turun (Fatihatussalimah, 2015). Dinamika penurunan muka airlaut, proses deposisi material dari lautan yang intensif dan pengaruh aktivitas dari daratan mengakibatkan terbentuknya bentuklahan yang bervariasi. Bentuklahan yang dapat ditemui di wilayah kepesisiran ngambur berupa gisik (M1), beting gisik (M2) dan dataran aluvium kepesisiran (Fm). Penurunan muka air laut juga menyebabkan terbentuknya endapan material berupa pasir dan lumpur, selain itu air laut dapat terjebak pada area-area tertentu yang menyebabkan air tanah terasa payau hingga asin.

Permukiman warga saat ini terkonsentrasi pada wilayah beting gisik dan dataran fluviomarin. Guna memenuhi kebutuhan air sehari-hari, warga memanfaatkan sumur gali yang dibuat sendiri. Namun demikian terdapat beberapa warga yang harus membeli air karena sumur gali hanya menyediakan sedikit air dan saat proses penggalian sumur sering dijumpai padas sehingga dalam kondisi tertentu penggalian sumur terpaksa tidak dilanjutkan. Kebutuhan akan air tanah ini menjadi lebih terasa ketika musim kemarau dimana air tanah pada sumur-sumur warga cenderung mengalami penurunan.

Keberadaan air tanah di wilayah kepesisiran ngambur berada dalam satu lapisan akuifer, yaitu formasi batuan yang memiliki sifat mudah menerima, menyimpan, dan meluluskan air dalam jumlah cukup. Distribusi keberadaan air tanah tawar (freshgroundwater) belum diketahui secara detil. Guna memperoleh informasi ini diperlukan pengukuran dengan menggunakan geolistrik untuk merekonstruksi penampang hidrostratigrafi wilayah kajian.

Hidrostratigrafi merupakan sebuah metode atau cara untuk mengilustrasikan tentang susunan dan sistem perlapisan batuan dibawah permukaan tanah sampai pada kedalaman tertentu yang menekankan pada upaya untuk menunjukkan sistem, dan kedudukan akuifer (Santosa, 2010; Santosa dan Adji, 2014), dalam upaya menentuan sistem perlapisan batuan, sifat perlapisan batuan dan sifat air tanah yang terkandung didalamnya, diperlukan data tahanan jenis (resistivitas). Data tersebut dapat diperoleh dengan cara pengukuran langsung di lapangan menggunakan teknik survei geolistrik (geoelectric survey). Purnama (2010) memaparkan geolistrik dapat digunakan untuk 
Jurnal geoedusains, Volume 2, Nomor 1, Juni 2021

mengidentifikasi perbedaan tahanan jenis batuan khususnya akuifer di lapangan. Menurut Todd (1980) Variasi nilai resistivitas batuan dipengaruhi oleh kemampatan batuan, ukuran, bentuk pori, kandungan air, serta suhu material. Dengan demikian, material-material batuan penyusun akuifer dapat diketahui dengan menginterpretasikan nilai resistivitas yang terukur.

\section{Metode Penelitian}

Metode yang digunakan dalam melakukan penelitian ini adalah survei lapangan untuk mengumpulkan data primer berupa nilai resistivitas. Penentuan titik pengukuran menggunakan metode purposive sampling. Metode ini dipilih karena pengukuran geolistrik dilakukan dengan mempertimbangkan kriteria 3 jenis bentuklahan yaitu gisik (M1), beting gisik (M2) dan fluviomarin.

Geolistrik untuk keperluan pendugaan perlapisan material tanah secara vertikal menggunakan metode Vertical Electrical Sounding (VES), dengan metode ini dapat diketahui nilai resistivitas material secara vertikal dalam jangkauan tertentu. Hasil pengukuran geolistrik berupa data kuat arus (I), beda potensial (v) dan jarak antar elektroda (a). Data tersebut digunakan untuk menghitung nilai resistivitas semu ( $p a)$ dengan menggunakan rumus :

$$
p a=\mathrm{k} \frac{V}{I}
$$

Hasil penghitungan nilai resistivitas semu (pa) dalam satuan ohm ( $\Omega \mathrm{m})$ tersebut harus diubah menjadi nilai resistivitas sebenarnya sehingga perlu diolah dengan menggunakan software IP2Win. Pengolahan data dengan menggunakan IP2Win meliputi 4 tahapan yaitu input data, koreksi eror, penambahan titik dan penampilan cross section. Hasilnya berupa model 2 dimensi stratigrafi material pada masing-masing titik ukur. Agar model stratigrafi benar-benar merepresentasikan lapisan material di lapangan maka diperlukan data penunjang lain yaitu tabel nilai resistivitas.

Terdapat banyak klasifikasi resistivitas material dari peneliti Indonesia maupun peneliti dari luar negeri, namun klasifikasi resistivitas material batuan yang digunakan tetap berdasarkan pada hasil penelitian terdahulu yang dilakukan di Indonesia dengan mempertimbangkan kecocokan kondisi geologi dan geomorfologi yang ada. Kondisi geomorofologi wilayah kajian yang berupa marine deposition coast memiliki kesamaan 
Jurnal geoedusains, Volume 2, Nomor 1, Juni 2021

dengan penelitian sebelumnya yang dilakukan oleh Santosa (2012) di wilayah kepesisiran Kulonprogo (Tabel 3.4).

Tabel 1 Nilai Resistivitas Material

\begin{tabular}{|c|c|c|}
\hline No & Resistivitas ( $(\Omega)$ & Material \\
\hline \multirow{2}{*}{\multicolumn{3}{|c|}{$\begin{array}{c}\text { Satuan Bentuklahan Gisik, Kompleks Beting Gisik, Swale, dan Gumuk } \\
\text { Pasir }\end{array}$}} \\
\hline & & \\
\hline 1 & $>750$ & Pasir marin-eolian kering (indikasi zona aerasi) \\
\hline 2 & $25-750$ & Pasir marin jenuh air tanah tawar indikasi akuifer \\
\hline 3 & $10-25$ & $\begin{array}{l}\text { Lempung marin bercampur lanau dan pasir marin } \\
\text { halus mengandung air tanah payau indikasi } \\
\text { akuitard }\end{array}$ \\
\hline 4 & $1-10$ & $\begin{array}{l}\text { Lempung marin mengandung air tanah payau } \\
\text { indikasi akuitard. }\end{array}$ \\
\hline 5 & $<1$ & $\begin{array}{l}\text { Lempung marin mengandung air tanah asin } \\
\text { indikasi zona interface }\end{array}$ \\
\hline \multicolumn{3}{|c|}{ Satuan Bentuklahan Dataran Fluviomarin } \\
\hline 6 & $>250$ & $\begin{array}{l}\text { Material permukaan yang masih dipengaruhi } \\
\text { fluktuasi permukaan air tanah bebas indikasi zona } \\
\text { aerasi }\end{array}$ \\
\hline 7 & $25-250$ & $\begin{array}{l}\text { Aluvium sungai mengandung air tanah tawar } \\
\text { indikasi akuifer }\end{array}$ \\
\hline 8 & $10-25$ & $\begin{array}{l}\text { Lempungmarin terkadang mengandung fosil } \\
\text { moluska lithoral berselang-selign dengan aluvium } \\
\text { sungai dan mengandung air tanah payau Indikasi } \\
\text { akuitard }\end{array}$ \\
\hline 9 & $1-10$ & $\begin{array}{l}\text { Lempung marin berselang-seling dengan lanau } \\
\text { dan pasir marin halus mengandung fosil-fosil } \\
\text { moluska lithoral dan air tanah payau hingga asin } \\
\text { indikasi selang-seling akuiklud-akuitard. }\end{array}$ \\
\hline
\end{tabular}

Sumber : Santosa (2012)

Pengukuran geolistrik dilakukan pada 24 titik pendugaan, seluruh titik pendugaan tersebut tersebar pada 3 bentuklahan yaitu gisik, beting gisik dan fluviomarin. Hal ini dilakukan dengan pertimbangan untuk mengetahui hidrostratigrafi pada masing-masing bentuklahan. Peta pendugaan geolistrik disertakan pada Gambar 1.

Kajian Hidrostratigrafi Bentanglahan Kepesisiran ...

Evi Mivtahul Khoirullah, I.g.L.Setyawan Purnama, Margaretha Widyastuti 


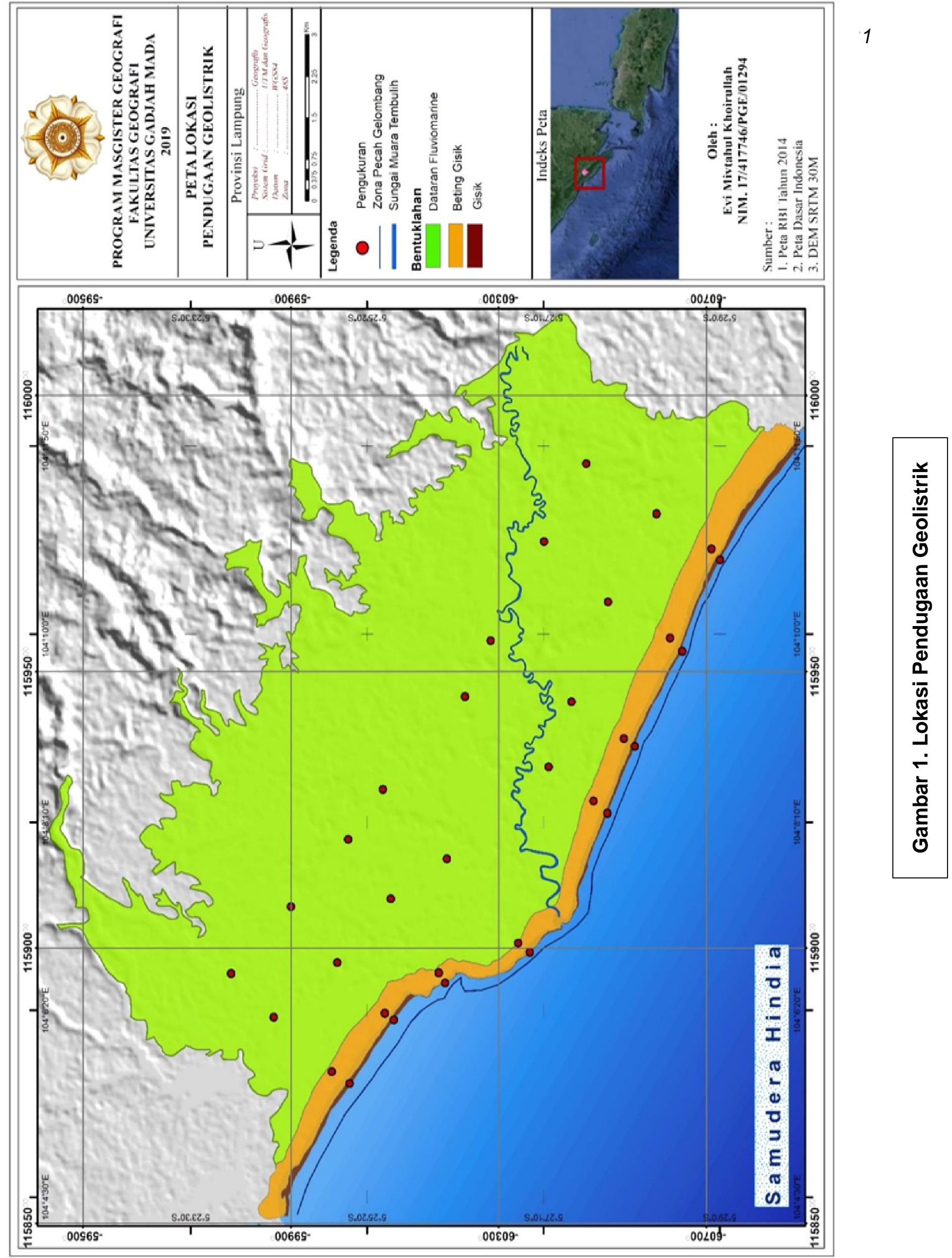

Kajian Hidrostratigrafi Bentanglahan Kepesisiran ... 


\section{Pembahasan}

\section{Penampang Pada Bentuklahan Gisik}

Berdasarkan hasil pendugaan geolistrik, kepesisiran Ngambur secara umum memiliki akuifer yang dapat dapat ditemukan pada lapisan pasir marin dan aluvium. Berikut merupakan rekonstruksi hidrostratigrafi pada bentuklahan gisik.

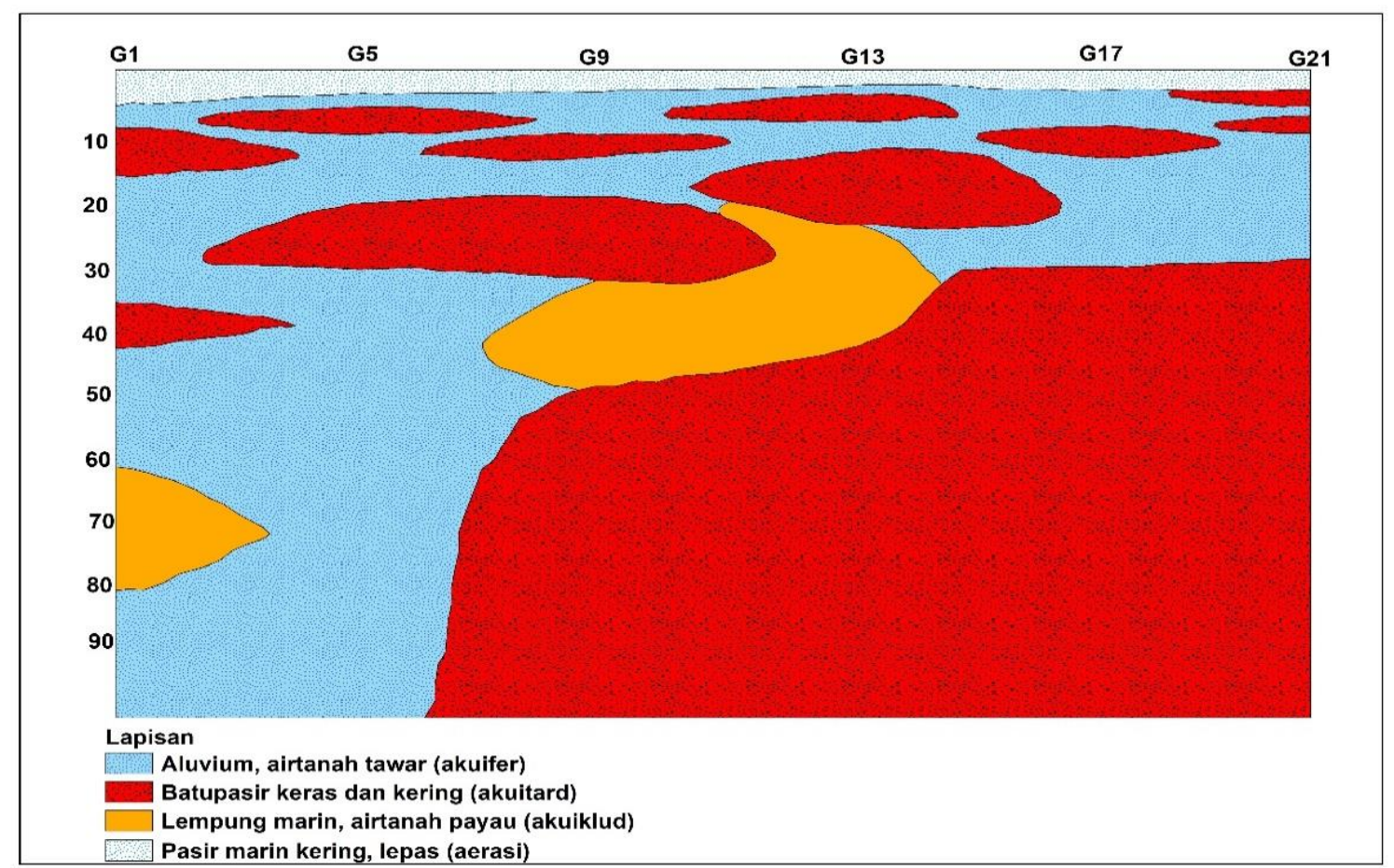

Gambar 2. Penampang Hidrostratigrafi Pada Bentuklahan Gisik.

Penampang pada bentuklahan gisik ini terletak tepat di area terluar wilayah kajian dengan formasi geologi Qa. Titik pengukuran yang terhubungkan yaitu titik G1, G5, G9, G13, G17, dan G21. Terdapat 5 jenis lapisan material yang semuanya tidak terhubung secara utuh dalam 6 titik. Lapisan paling atas berupa pasir marin kering air tanah sebagai zona aerasi. Pada lapisan dibawahnya terdapat material aluvium mengandung air tanah tawar yang berperan sebagai zona akuifer.

Pengukuran pada titik G1, G5, G9, G13, G17, G21 didominasi oleh material aluvium dan batupasir, menurut Loke (2000) batupasir terbentuk dari proses sedimentasi material pasir yang tersementasi secara bersamaan. Pasir yang mengandung air tanah tawar pada bentuklahan gisik ini dapat ditemukan pada kedalaman terntentu dengan bantuan klasifikasi material yang dibuat oleh santosa (2012). Menurut Telford (1990) air tanah memiliki nilai resistivitas $0.5-300 \Omega$, namun pada pendugaan kali ini hanya beberapa titik tertentu yang memiliki nilai resistivitas dalam rentang tersebut, dengan dibantu klasifikasi hidrostratigrafi dari sumber lain memudahkan proses analisis dan identifikasi lapisan yang 
Jurnal geoedusains, Volume 2, Nomor 1, Juni 2021

mengandung airtanah. Informasi yang diberikan oleh penduduk selama penelitian juga sangat membantu untuk interpretasi hasil pengukuran.

Secara umum sistem perlapisan batuan yang teridentifikasi berupa aerasi, akuifer bebas, akuiklud dan akuitard. Material akuitard pada kedalaman 2 - 30 mdpt pada masing-masing titik tidak terhubung dan tidak selaras. Perlapisanmaterial terputus dengan ketebalan berbeda-beda. Sistem perlapisan batuan akuiklud dengan sifat mampu menyerap air namun sulit melepaskannya berada pada kedalaman > 20 mdpt, dengan kedalaman seperti ini kemungkinan besar keberadaan akuiklud ini disebabkan oleh proses alam.

\section{Penampang Pada Bentuklahan Beting Gisik}

Penampang pada bentuklahan Beting gisik ini menghubungkan antara titik G2, G6, G10, G14, G18 dan G22. Pada bentuklahan beting gisik ini ditemukan beberapa titik yang terdeteksi adanya lempung marin dengan dugaan air tanah payau. masing-masing titik tersebut adalah G2, G10, dan G14. Mempertimbangkan kedalaman lapisan lempung yaitu > 10 mdpt, tidak ada aktivitas manusia yang mungkin mempengaruhi kondisi air tersebut. Kemungkinan besar air payau tersebut merupakan hasil dari aktivitas airlaut yang merembes ke daratan sehingga mempengaruhi kondisi air pada area tertentu.

Setidaknya terdapat 5 zona yang teridentifikasi, yaitu zona aerasi berupa material pasir kering yang terletak di permukaan, zona akuifer bebas mendominasi keseluruhan akuifer pada penampang ini. Zona akuiklud yaitu lempung dengan sifatnya yang mampu menyerap air namun sangat sukar untuk meluluskannya. Zona akuitard berupa batupasir marin keras dan kering dan zona akuifer tertekan yang terletak pada titik pengukuran G2, G6, G10 pada kedalaman > 13 mdpt. Formasi batupasir dalam penampang ini tidak terkorelasi dan tidak selaras, terputus pada masing-masing titik. Namun demikian batupasir pada lapisan paling bawah terlihat memanjang menghubungkan antara titik G6 G22. 


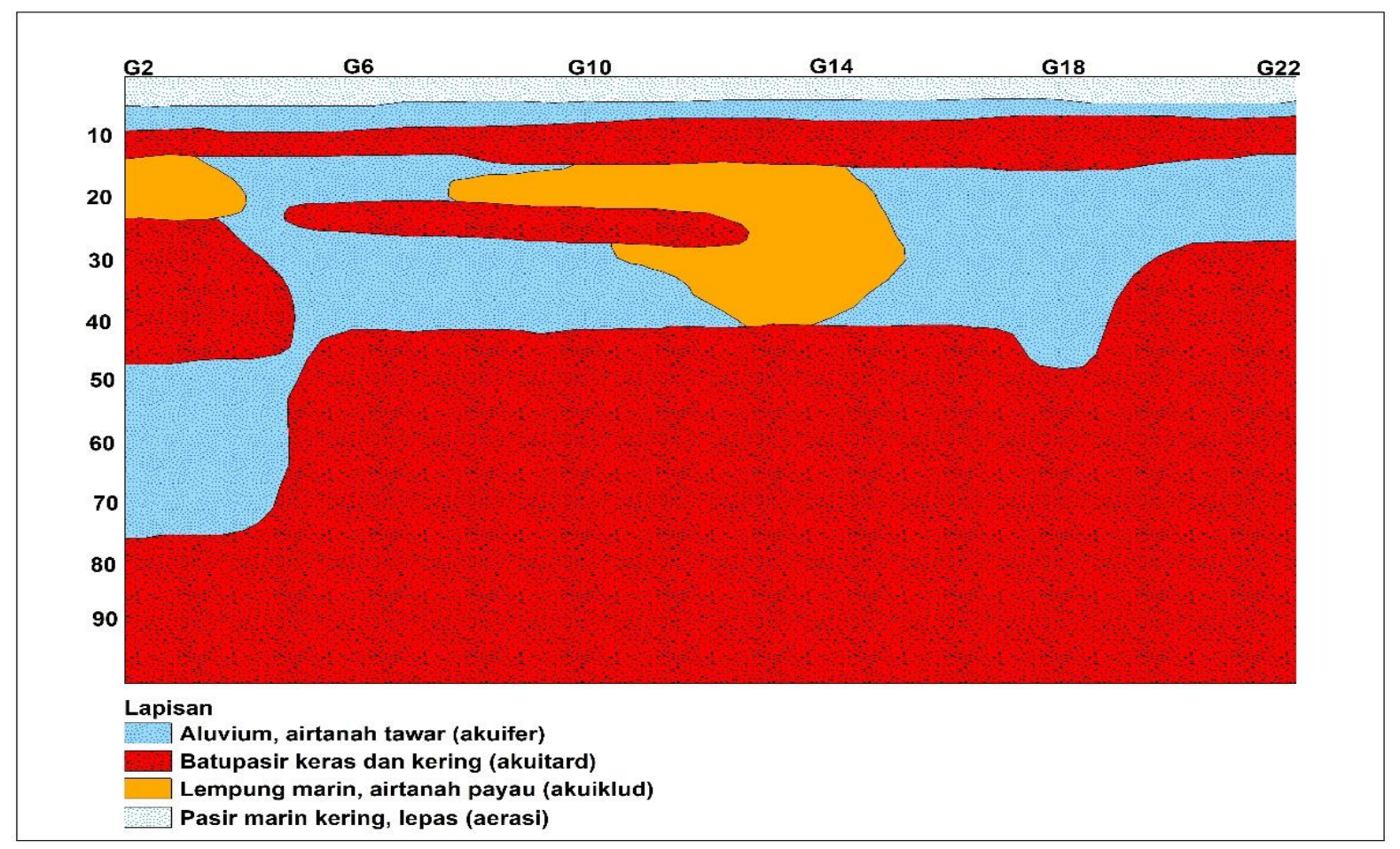

Gambar 3. Penampang Hidrostratigrafi Pada Beting Gisik.

\section{Penampang Hidrostratigrafi Pada Bentuklahan Fluviomarin 1}

Penampang hidrostratigrafi ini menghubungkan 6 titik yaitu G3, G7, G11, G15, G19, G23 dengan formasi geologi Tmps. Lapisan paling atas berupa material permukaan yang masih dipengaruhi oleh fluktuasi airtanah, sehingga lapisan ini berfungsi sebagai zona aerasi. Lapisan ini berada pada kedalaman 0-3 mdpt. Lapisan paling bawah berupa material batu pasir keras dengan kedalaman bervariasi antar titik namun masih terhubung dan saling terkorelasi. Material lain berupa batuan konglomerat dan lempung marin yang diduga mengandung air tanah payau tidak saling terhubung pada masing-masing titik. Zona akuifer paling dalam berada pada titik G7 dengan kedalaman 65 mdpt. Secara umum penampang hidrostratigrafi pada bentuklahan fluviomarin ini didominasi oleh material batupasir yang terkorelasi pada masing-masing titik dan selaras terdapat pada lapisan paling bawah yang berhasil teridentifikasi. Keberadaan lapisan lempung marin dengan kandungan air tanah payau ditemukan dibawah lapisan akuifer pada titik G3, G11, G15, G19 dan G23. Berikut ini adalah model penampang hidrostratigrafi pada bentuklahan fluviomarin 1. 


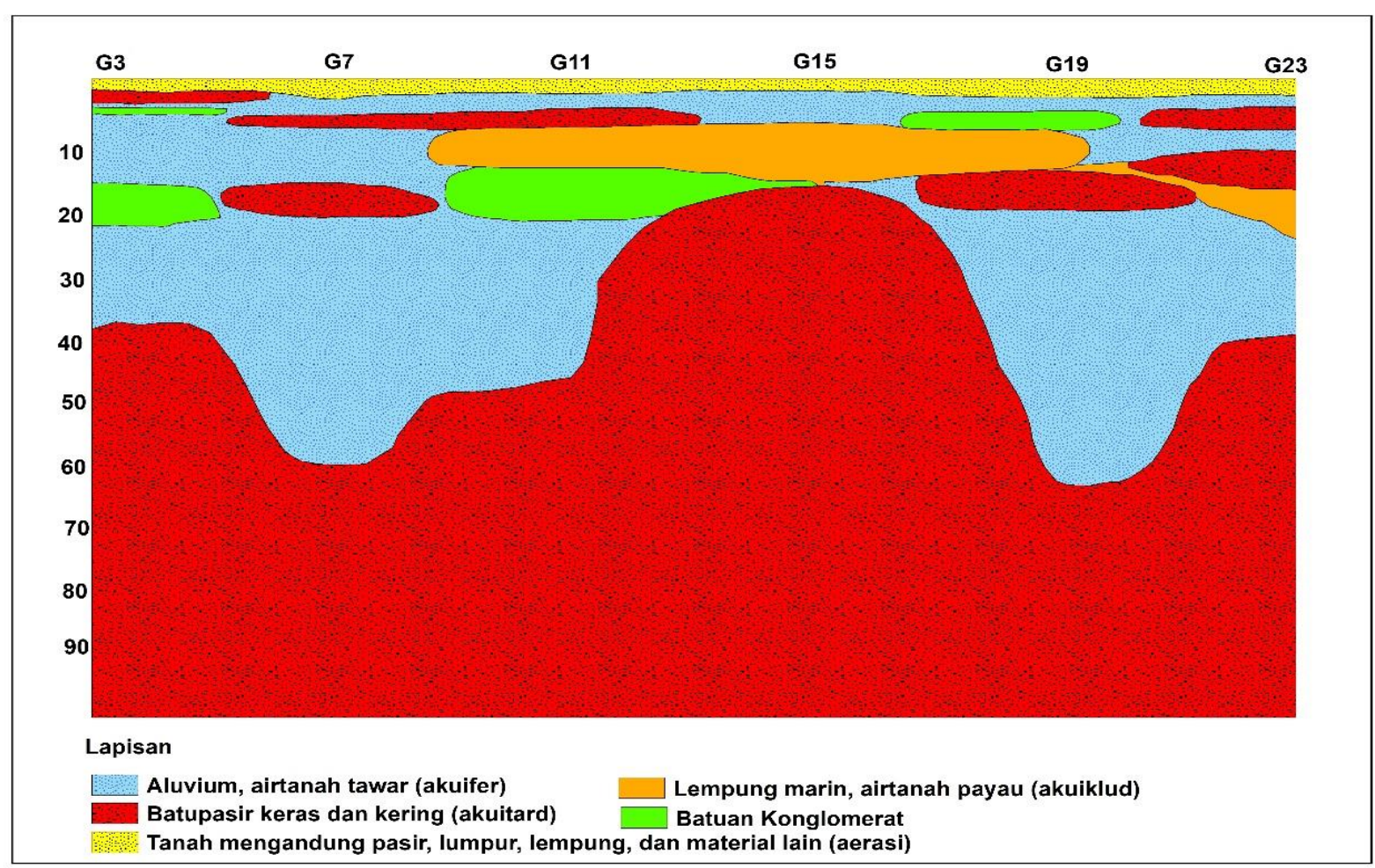

Gambar 4. Penampang Hidrostratigrafi Fluviomarin 1.

\section{Penampang Hidrostratigrafi Pada Bentuklahan Fluviomarin 2}

Penampang hidrostratigrafi pada dataran fluviomarin ke 2 ini menghubungkan titiktitik pendugaan yang berada pada area paling utara wilayah kajian yang berdekatan dengan tekuk lereng perbukitan barisan selatan dengan formasi geologi Tmps. Pada penampang ini ditemukan material dengan nilai resistivitas sangat tinggi hingga puluhan ribu yang berada pada kedalaman $>20$ mdpt. Material ini diduga merupakan batuan breksi vulkanik yang berasal dari formasi QV. Formais QV ini berumur lebih tua dari formasi Tmps dan letaknya berada dibawah formasi Tmps. Menurut sejarah genesa wilayah ini, pernah terjadi aktivitas tektonik berupa pengangkatan dan penenggelaman lempeng benua dibarengi dengan erupsi gunungapi hebat pada masa plio-pleistosen. Material breksi gunungapi ini bisa jadi terbentuk pada masa tersebut.

Namun demikian tidak ada bukti yang tepat dan akurat mengenai jenis material ini, juga terbatasnya data-data penelitian yang pernah dilakukan sebelumnya. Perlu dilakukan penelitian lebih lanjut untuk menegtahui detil material secara lebih akurat. Berikut ini merupakan penampang hidrostratigrafi pada bentuklahan fluviomarin ke 2 . 


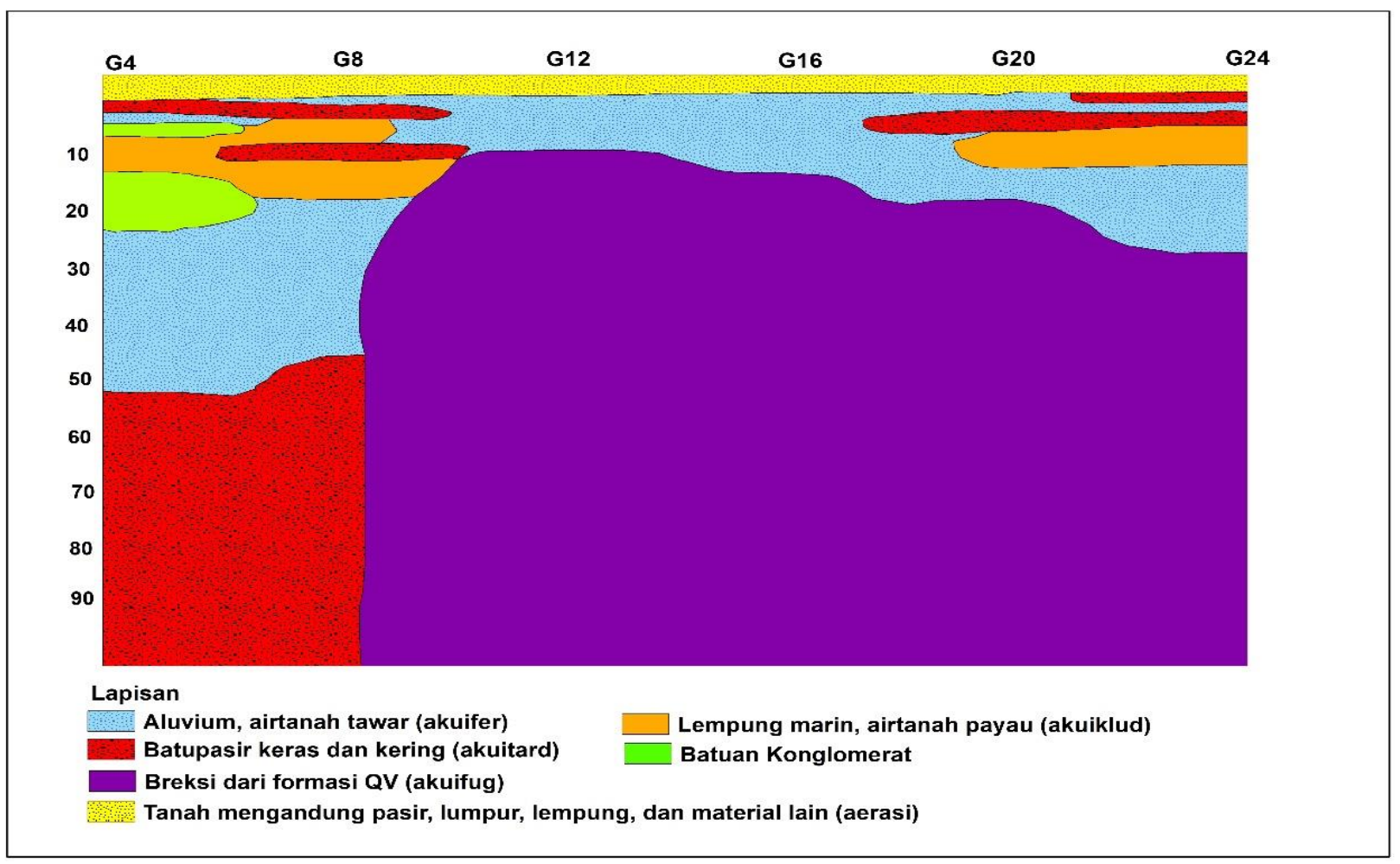

Gambar 5. Penampang Hidrostratigrafi Fluviomarin 2

\section{Karakteristik Hidrostratigrafi}

Beradasarkan pengukuran dengan geolistrik dan rekonstruksi penampang hidrostratigrafi, daerah kepesisiran Ngambur memiliki akuifer yang terdapat pada lapisan aluvium. Keberadaan material aluvium sungai yang bertemu dengan pasir marin sebagai ciri khas wilayah kepesisiran tidak begitu tampak pada penelitian kali ini. Ciri khas zonasi wilayah kepesisiran yang tampak dari hasil pendugaan berupa adanya jebakan material lempung mengandung fosil moluska lithoral dengan air tanah asin pada bentuklahan fluviomarin.

Guna mempermudah pengklasifikasian, material pasir marin yang mengandung air tanah tawar dan material aluvium sungai disatukan dengan sebutan aluvium. Pengklasifikasian material tidak dilakukan dengan menggunakan pendekatan tabel saja, tetapi juga dilakukan analisis mendalam terkait komposisi geologi dan proses geomorfologi yang pernah terjadi. Sebagai contoh, dalam menentukan dua jenis material antara pasir kering lepas dan batupasir, dengan nilai resistivitas yang tinggi hingga mencapai ribuan ohm (' $\Omega$ ) sering kali diklasifikasikan sebagai batupasir keras dan kering, namun demikian apabila material tersebut berada pada permukaan tanah, pada bentuklahan gisik atau beting gisik maka nilai tersebut lebih mendekati pada material pasir marin lepas dan kering. Namun jika material yang teridentifikasi ribuan $\Omega$ tersebut berada Kajian Hidrostratigrafi Bentanglahan Kepesisiran ... 
Jurnal geoedusains, Volume 2, Nomor 1, Juni 2021

pada jauh didalam tanah bisa jadi material tersebut berupa batupasir yang sudah kompak. Dugaan ini juga diperkuat lagi dengan data yang diperoleh dari peta geologi.

Batuan sedimen seperti batupasir memiliki permeabilitas yang tinggi tergantung ukuran butir material penyusunnya. Material yang berbutir kasar dan lepas dapat bertindak sebagai akuifer, sedangkan material yang berbutir kecil dan padu dapat bertindak sebagai akuitard (Kodoatie, 2012). Hasil penelitian dilapangan menunjukkan bahwa material batupasir memiliki nilai resistviitas yang tinggi hingga mendekati $10.000 \Omega$ hal ini menunjukkan bahwa material batupasir ini memiliki karakteristik padas dan tidak memiliki kandungan air tanah di dalamnya.

Pada beberapa titik pengukuran juga ditemui lapisan yang diduga merupakan air tanah payau. Pada bentuklahan gisik, air tanah payau tersebut diduga berasal dari aktivitas marin yang mempengaruhi ion dalam air tanah di daratan. Pada bentuklahan fluviomarin, keberadaan air tanah payau ini duga berasal dari jebakan air laut pada masa lampau. Pada bentuklahan gisik, material lempung dengan kandungan artanah payau ditemukan dalam bentuk lapisan-lapisan tipis, namun demikian pada bentuklahan fluviomarin ditemukan lapisan lempung marin dengan air tanah payau yang cukup tebal. Kita bisa menghindari pengambilan air tanah pada area tersebut.

Perembesan air asin dari lautan ke air tanah tawar di daratan disebut engan intrusi. Menurut Purnama (2010) intrusi terjadi apabila kesetimbangan antara muka air tawar dan muka air asin terganggung. Menurut FAO (1997) penyebab terjadinya air asin didalam tanah selain intrusi yaitu : a) air fosil atau air laut yang terjebak di daratan pada masa geologi lampau., b) terjadinya penguapan yang intensif pada alguna dan daerah yang tertutup lainnya., c) pancaran angin laut disepanjang pantai akibat angin laut uang terlalu kencang., d) pasang surut serta badai yang terjadi pada area estuaria., e) pelarutan batuan evaporit oleh airtanah., f) air asin dan kubah garam., g) limbah pertanian dan limbah domestik., h)aliran balik dari air irigasi.

\section{Sistem Perlapisan Batuan}

Sistem perlapisan batuan mencakup jenis akuifer yang ada pada wilayah kajian. Interpretasi nilai resistivitas, geologi, dan hasil penggambaran model penampang hidrostratigrafi dapat dirangkum terdapat beberapa jenis akuifer (zona) yang membentuk sistem perlapisan batuan di wilayah kajian. Zona tersebut berupa :

a. Zona aerasi, terletak pada lapisan paling atas (permukaan) yang masih terpengaruhi oleh fluktuasi air tanah yang ada. Zona aerasi pada bentuklahan gisik dan beting gisik 
Jurnal geoedusains, Volume 2, Nomor 1, Juni 2021

formasi geologi Qa ini tersusun atas material pasir marin lepas, porus, dan kering. Pada bentuklahan fluviomarin formasi geologi Tmps berupa material tanah bercampur pasir, lumpur kering, dan material lain.

b. Zona akuifer bebas, teridentifikasi tersebar merata di seluruh wilayah kajian dengan ciri khas lapisan material diatasnya berupa zona aerasi dan lapisan bawah berupa lapisan yang impermeable.

c. Zona akuifer tertekan, teridentifikasi pada titik :

1. G9 dan G10, air tanah tawar terindikasi berada pada kedalaman $>30$ mdpt yang terhimpit oleh 2 lapisan impermeable berupa batupasir keras dan kering, serta terhalangi oleh lempung marin yang bersifat akuiklud.

2. G13 pada kedalaman $10 \mathrm{mdpt}$, air tanah tawar telihat mengisi ruang kecil diantara 2 lapisan material batupasir keras dan kering dan terhalang oleh lempung marin yang bersifat akuiklud.

3. G17, G18, G19, G20 dengan kedalaman > 20 mdpt, teridentifikasi akuifer tertekan yang diapit oleh material batupasir keras dan kering serta material batuan breksi yang berfungsi sebagai akuifug.

d. Zona akuifer sekunder berupa indikasi batuan konglomerat. Batuan konglomerat menjadi akuifer sekunder karena memiliki banyak pori-pori sekunder (berongga).

e. Zona akuiklud, berupa material lempung dengan kandungan air tanah payau ditemukan pada beberapa titik pengukuran.

f. Zona akuitard, berupa material batupasir keras dan kering tersebar di banyak tempat. Hampir keseluruhan wilayah kepesisiran ngambur tersusun atas material batupasir keras dan kering.

g. Zona akuifug, teridentifikasi pada lapisan material yang diduga merupakan breksi gunungapi dari formasi Qv.

\section{Sifat Perlapisan Batuan}

Sifat perlapisan batuan pada wilayah kajian meliputi jenis material penyusun dan hambatan jenis. Secara umum material penyusun lapisan akuifer pada wilayah kajian berupa material aluvium yaitu material campuran endapan lepas yang berukuran batu kerikil, pasir hingga yang lebih halus seperti debu dan lempung. Material lain yang dominan berupa batupasir hasil proses sedimentasi yang menjadi material padu. Beberapa hal yang dapat mempengaruhi nilai resistivitas yaitu porositas batuan, konsentrasi garam terlarut, dan derajat kejenuhan air (Loke, 2012). Nilai resisitivitas yang Kajian Hidrostratigrafi Bentanglahan Kepesisiran ... 
Jurnal geoedusains, Volume 2, Nomor 1, Juni 2021

terukur bervariasi, semakin tinggi nilai resistivitas menunjukkan kandungan air tanah semakin sedikit atau bahkan tidak ada samasekali.

Pada penelitian kali ini ditemukan material yang memiliki nilai resistivitas tinggi dengan porositas tinggi yaitu material pasir marin kering yang terletak pada lapisan tanah atas. Namun demikian ditemukan juga material dengan nilai resistivitas tinggi namun sifat batuan padu, ditemukan pada lapisan tanah dalam berupa batupasir keras dan kering dengan nilai resistivitas hingga mencapai $10.000 \Omega$. Detil jenis material dan nilai resistivitas terukur disertakan dalam lampiran.

\section{Kesimpulan}

Berdasarkan pengukuran geolistrik pada daerah penelitian dapat disimpulkan bahwa :

1. Sistem perlapisan batuan di wilayah kajian berupa zona aerasi, akuifer bebas, akuifer tertekan, akuifer sekunder, akuiklud, akuitard dan akuifug.

2. Pada area tertentu ditemukan material lempung dengan kandungan air tanah payau, lapisan material ini terletak pada kedalaman tertentu dan tidak terjangkau oleh sumur warga sehingga keberadaan air tanah payau tersebut tidak berpengaruh secara langsung terhadap kualitas air tanah warga.

3. Lapisan akuifer dangkal pada area tertentu tidak terlalu tebal dan terhalang oleh material batupasir sehingga menghambat panurapan air tanah melalui sumur konvensional, hal ini yang menjadi penyebab terjadinya penurunan muka air tanah pada saat musim kemarau sehingga beberapa sumur warga tidak banyak menyediakan air tanah pada saat musim kemarau.

4. Material breksi vulkanik yang terdeteksi, tidak disebutkan dalam komposisi material geologi formasi Tmps. Namun demikian wilayah ini memang dikelilingi oleh formasi Qv dengan material breksi vulkanik dan lava andesit. Keberadaan material batuan breksi ini dapat dijadikan sebagai temuan baru untuk menambah komposisi peta geologi saat ini.

\section{Daftar Pustaka}

Fatihatussalimah, D. 2015. Geologi Indonesia Pola Tektonik Pulau Sumatra. Purbalingga: Universitas Jendral Soedirman.

Purnama, S. 2010. Manajemen Air tanah Berbasis Cekungan Airtanah. Yogyakarta: Penerbit Kanisius.

Santosa, Langgeng Wahyu. 2010. Pengaruh Genesis Bentuklahan terhadap Hidrostratigrafi Akuifer dan Hidrogeokimia dalam Evolusi Air tanah Bebas - Kasus pada Bentanglahan Kepesisiran Kabupaten Kulonprogo, Daerah Istimewa Yogyakarta. Disertasi. Yogyakarta : Fakultas Geografi, UGM.

Kajian Hidrostratigrafi Bentanglahan Kepesisiran ...

Evi Mivtahul Khoirullah, I.g.L.Setyawan Purnama, Margaretha Widyastuti 
Jurnal geoedusains, Volume 2, Nomor 1, Juni 2021

Santosa, Langgeng Wahyu, \& Adji, T. N. 2014. Karakteristik Akuifer dan Potensi Air tanah Graben Bantul. Yogyakarta: Gadjah Mada University Press.

Todd, D. K. 1980. Groundwater Hydrology. Newyork : John Wiley and Sons. 